\title{
THE SOUTH CHINA SEA ARBITRATION AND NEW ZEALAND'S MARITIME CLAIMS
}

Joanna Mossop*

The decision in the South China Sea arbitration in relation to the interpretation of art 121(3) of the United Nations Convention on the Law of the Sea has broad implications for states not party to the case. New Zealand, like many other countries, claims an exclusive economic zone and continental shelf from uninhabited islands, but no other state has objected to those claims. This article applies the South China Sea approach to art 121(3) to show that, if strictly followed, some maritime features that have been regarded as islands might be classified as rocks not capable of generating maritime zones. The article critiques the reasoning of the Arbitral Tribunal, and suggests that another tribunal might not follow its interpretation of art 121(3). In addition, in cases where coastal states such as New Zealand have long-standing claims from uninhabited features, it may be possible to argue that other states cannot challenge these claims based on acquiescence.

\section{INTRODUCTION}

The arbitral award in the South China Sea case has sent reverberations around the international community, especially in relation to its decisions about the status of the various features in the South China Sea. ${ }^{1}$ The Tribunal made a number of determinations about the interpretation of art 121(3) of the United Nations Convention on the Law of the Sea (UNCLOS) ${ }^{2}$ which states that "rocks which

* Associate Professor from 1 January 2018, School of Law, Victoria University of Wellington. An early draft of this article was used as the basis for brief comments to be published in the ASIL Proceedings of the 110th Annual Meeting, 2017. The author thanks Alberto Costi for his comments on a draft of this article.

1 South China Sea Arbitration (Philippines v China) (Award) (2016) 55 ILM 811 [South China Sea Arbitration (Award)]. The Tribunal uses "features" in reference to naturally formed areas of land above water at high tide where there is a question about their legal classification. Technically, all areas of land above the high water mark are "islands" (see art 121(1)). Paragraph 3 creates a sub-set of islands, which are "rocks which cannot sustain human habitation or economic life of their own". An island is capable of generating a full set of maritime zones, but a rock cannot generate an exclusive economic zone or continental shelf.

2 United Nations Convention on the Law of the Sea 1833 UNTS 397 (opened for signature 10 December 1982, entered into force 16 November 1994) [UNCLOS]. 
cannot sustain human habitation or economic life of their own shall have no economic zone or continental shelf". It concluded that none of the features in consideration in the case were capable of generating an exclusive economic zone (EEZ) or continental shelf. In doing so, the Tribunal made a number of observations about the interpretation of art 121(3) that have potential application to features in other parts of the world. ${ }^{3}$ This article explores whether the Award threatens existing maritime claims derived from small islands, with a focus on New Zealand's claims. It shall be seen that the impact of the Tribunal's jurisprudence on article 121(3) may be limited in such cases.

New Zealand has a number of offshore islands which form the basis of claims to an EEZ and continental shelf. In some cases, these islands are small and uninhabited. ${ }^{4}$ In other cases, they are large and have a history of habitation, although the Chatham Islands are the only offshore islands that still sustain a population. ${ }^{5}$ New Zealand is not alone in claiming an EEZ and continental shelf from remote islands. Some of these claims are controversial and their classification under art 121(3) has been challenged. These controversial claims include the Savage Islands, ${ }^{6}$ Aves Island, ${ }^{7}$ and Okinotorishima. ${ }^{8}$ In other cases, states have claimed an EEZ and continental shelf from features that have not attracted protest from other states. These include the United States in respect of Johnson

3 Many summaries of the award have been published. See for example Lucy Reed and Kenneth Wong "Marine Entitlements in the South China Sea: The Arbitration between the Philippines and China" (2016) 110 AJIL 746; Bernard Oxman "The South China Sea Arbitration Award" (6 September 2016) Social Science Research Network <www.ssrn.com>; Duncan French "In the Matter of the South China Sea Arbitration" (2017) 19 Environmental Law Review 48; and Nilufer Oral "Rocks or Islands? Sailing Towards Legal Clarity in the Turbulent South China Sea" (2016) 110 AJIL Unbound 279.

4 Namely, the Antipodes, Bounty and Snare islands.

5 Larger islands with a history of settlement include Raoul Island in the Kermadec chain, Auckland Islands and Campbell Islands.

6 Claimed by Portugal, protested by Spain. See Clive R Symmons "Maritime Zones from Islands and Rocks" in S Jayakumar, Tommy Koh and Robert Beckman (eds) The South China Sea Disputes and Law of the Sea (Edward Elgar, Cheltenham (UK), 2012) 55 at 108.

7 Claimed by Venezuela, protested by Antigua and Barbuda, St Kitts and Nevis, Saint Lucia and St Vincent and the Grenadines; accepted by the United States, France and the Netherlands in delimitation treaties. See J Ashley Roach and Robert W Smith Excessive Maritime Claims (3rd ed, Martinus Nijhoff, Leiden, 2012); Symmons, above n 6, at 109; and Jon M Van Dyke, Joseph R Morgan and Jonathan Gurish "The Exclusive Economic Zone of the Northwestern Hawaiian Islands: When Do Uninhabited Islands Generate an EEZ?" (1988) 25 San Diego L Rev 425 at 430.

8 Claimed by Japan, protested by China and South Korea. See Symmons, above n 6, at 109-110; Guifang (Julia) Xue "How Much Can a Rock Get? A Reflection from the Okinotorishima Rocks" in Myron H Nordquist and others (eds) The Law of the Sea Convention: US Accession and Globalization (Martinus Nijhoff, Leiden, 2012) 341; and Yann-Huei Song "The Application of Article 121 of the Law of the Sea Convention to the Selected Geographical Features Situated in the Pacific Ocean" (2010) 9 Chinese JIL 663 at 691. 
Atoll, Jarvis Island, Palmyra Atoll and Kingman Reef $;{ }^{9}$ France in respect of Clipperton Island and Matthew Island $;{ }^{10}$ Brazil in respect of St Peter and Paul rocks; ${ }^{11}$ and Australia in respect of the subAntarctic Heard Island and McDonald Islands. ${ }^{12}$ Similarly, New Zealand has never received any protest from any state to the effect that the EEZ generated from offshore features is illegitimate due to art 121(3).

For those states, like New Zealand, with uncontested claims based on uninhabited features, the award in the South China Sea arbitration raises the unwelcome prospect that such claims might be challenged in some way in the future. One possible scenario in which the argument might arise is where a coastal state arrests a foreign fishing vessel in an EEZ generated from a small feature. The fishing company or flag state could attempt to argue, either in a domestic or international forum, that the EEZ is invalid due to art 121(3). Rather than attempting a comprehensive analysis of the South China Sea Award, the purpose of this article is to determine whether such arguments would be successful, using New Zealand's maritime zones as an example.

The first step is to examine whether New Zealand's claims to maritime zones measure up against the jurisprudence set out by the Tribunal. The Tribunal set a very high bar in terms of what features will be capable of sustaining human habitation or an economic life of their own. It will be seen that, although many of New Zealand's offshore features would probably meet this bar, in a few cases they may not. However, this is not the end of the matter. The next section of the article critically examines the Tribunal's reasoning. It can be contended that the Tribunal's interpretation of art 121(3) has flaws that may mean its approach is not followed in other disputes that end up before a court or tribunal. Finally, the article argues that, even if the Tribunal's reasoning is adopted, the doctrine of acquiescence could prevent states challenging claims, like those of New Zealand, that are based on long-standing and uncontested practice. Where states have had multiple opportunities to object to New Zealand's claim over a long period of time, but have not done so, acquiescence may prevent those states from later arguing that its claim is invalid.

9 Jon M Van Dyke and Robert A Brooks "Uninhabited Islands: Their Impact on the Ownership of the Oceans' Resources" (1983) 12 Ocean Development and International Law 265 at 268; Song, above n 8, at 689-90 (regarding the Howland and Baker islands); and Van Dyke, Morgan and Gurish, above n 7, at 465 for a discussion of the Northern Hawaiian Islands.

10 Symmons, above n 6, at 110; and Song, above n 8, at 691.

11 Symmons, above n 6, at 111; and Song, above n 8, at 684 .

12 Declaration of Vice-President Vukas in The Volga Case (Russian Federation v Australia) (Judgment) (2003) 42 ILM 159 at 178-182; and Song, above n 8, at 685. 


\section{THE INTERPRETATION OF ARTICLE 121(3) OF UNCLOS}

\section{A Approaches to Article 121(3) prior to the Tribunal's Award}

Article 121(3) has long proved controversial. It is the result of deliberate ambiguity by the negotiators of UNCLOS. ${ }^{13}$ The negotiators were unable to reach agreement on which features should be disqualified from extended maritime zones based on size, presence of water and other characteristics, and so the formulation in art 121(3) avoids easily quantifiable criteria. ${ }^{14}$

The lack of clear criteria has inevitably led to a variable application of art 121(3). Some have taken a broad interpretation, arguing that art 121(3) would apply to many remote features and prevent them from generating maritime zones. This approach is generally taken by those states whose own maritime zones are potentially limited by another state's claim to maritime zones from the feature in question. Essentially, the argument is that the EEZ regime was intended to benefit local communities, not to confer a windfall on the owners of remote, uninhabited features. ${ }^{15}$ It has also been noted that the claim of a continental shelf around these features correspondingly reduces the amount of the seabed that is available to the Area, which is managed for the benefit of all mankind.

Others have taken a narrower interpretation of art 121(3), arguing that only the very smallest of features are incapable of human habitation or an economic life of their own. ${ }^{16}$ The proponents of this approach have tended to be those countries that are likely to benefit from extended maritime zones

13 Myron Nordquist and William G Phalen "Interpretation of UNCLOS Article 121 and Itu Aba (Taiping) in the South China Sea Arbitration Award" in Myron H Nordquist, John Norton Moore and Ronán Long (eds) International Marine Economy Law and Policy (Martinus Nijhoff, Leiden, 2017) 3 at 27; Marius Gjetnes "The Spratlys: Are They Rocks or Islands?" (2001) 32 Ocean Development and International Law 191 at 198; and Ted L McDorman "An International Law Perspective on Insular Features (Islands) and Low-tide Elevations in the South China Sea" (2017) 32 International Journal of Marine and Coastal Law 298 at 312.

14 Anderson has commented that "the lengthy discussions were marked by a lack of consensus" and "the records are not a reliable guide to the provision's interpretation": see David Anderson "Islands and Rocks in the Modern Law of the Sea" in Myron H Nordquist and others (eds) The Law of the Sea Convention: US Accession and Globalisation (Martinus Nijhoff, Leiden, 2012) 307 at 309 and 313. See also Clive Schofield "Islands or Rocks, is that the Real Question? The Treatment of Islands in the Delimitation of Maritime Boundaries" in Myron H Nordquist and others (eds) The Law of the Sea Convention: US Accession and Globalisation (Martinus Nijhoff, Leiden, 2012) 322 at 328. An in-depth examination of the negotiations and various proposals is provided by Victor Prescott and Clive Schofield (eds) Maritime Political Boundaries of the World (2nd ed, Martinus Nijhoff Publishers, Leiden, 2004) at 57-91. See also Jonathan I Charney "Rocks that Cannot Sustain Human Habitation" (1999) 93 AJIL 863; and Barbara Kwiatkowska and Alfred H Soons "Entitlement to Maritime Areas of Rocks Which Cannot Sustain Human Habitation or Economic Life of their Own" (1990) 21 NYIL 139.

15 Gjetnes, above n 13, at 194-196; Van Dyke, above n 7, at 437; and Van Dyke and Brooks, above n 9, at 288.

16 For example Prescott and Schofield, above n 14, at 82; and Anderson, above n 14, at 313. 
around their features. ${ }^{17}$ Although some states emphasised the importance of the Area, others focused on maximising the resources that were under the control of the coastal state. ${ }^{18}$ Both the EEZ regime and the extension of the continental shelf beyond 200 nautical miles reflect this perspective. Some have suggested that the negotiating history is incapable of providing an authoritative interpretation of art 121(3). ${ }^{19}$

A third approach to interpreting art 121(3) argues that there are three categories of feature: first, islands; secondly, rocks capable of sustaining human habitation and an economic life of their own; and thirdly, rocks not capable of sustaining human habitation and an economic life of their own. Only the last of these categories is excluded from generating an EEZ and continental shelf. Under this approach, larger islands would generate extended maritime zones even if they were not capable of human habitation or an economic life of their own. ${ }^{20}$ The advantage is that remote features of a large size would not be required to be subjected to the habitation/economic life analysis. ${ }^{21}$ The difficulty with this approach is that it begs the question about the difference between a rock and an island, as no size is stipulated in art 121, and no consensus could be reached in the UNCLOS negotiations. ${ }^{22}$ However, the proponents of this approach either propose their own minimum, or argue that the difference is obvious. ${ }^{23}$ Although it has been applied in at least one domestic tribunal, ${ }^{24}$ the approach

17 Opposing national interests was the reason that it was so difficult to achieve consensus on art 121(3). Clive Schofield "The Trouble with Islands: The Definition and Role of Islands and Rocks in Maritime Boundary Delimitation" in Seoung-Yong Hong and Jon M Van Dyke (eds) Maritime Boundary Disputes, Settlement Processes, and the Law of the Sea (Martinus Nijhoff, Leiden, 2009) 19 at 28.

18 Charney, above n 14, at 866; Alex G Oude Elferink "The Islands in the South China Sea: How Does their Presence Limit the Extent of the High Seas and the Area and the Maritime Zones of the Mainland Coasts?" (2001) 32 Ocean Development and International Law 169 at 174.

19 Alex G Oude Elferink "Clarifying Article 121(3) of the Law of the Sea Convention: The Limits Set by the Nature of International Legal Processes" (1998) IBRU Boundary and Security Bulletin 58.

20 Stefan Talmon "Article 121" in Alexander Proelss (ed) United Nations Convention on the Law of the Sea: A Commentary (CH Beck Verlag, Munich, 2017) 858, at 871. See also Roger O'Keefe "Palm-Fringed Benefits: Island Dependencies in the New Law of the Sea" (1996) 45 ICLQ 408 at 412; Anderson, above n 14, at 311; Barry Hart Dubner "The Spratly 'Rocks' Dispute - A 'Rockapelago' Defies Norms of International Law" (1995) 9 Temple International and Comparative Law Journal 291 at 303; and Gjetnes, above n 13, at 194. It has been argued that this was the approach taken by the Jan Mayen Conciliation Commission: see O'Keefe, above $\mathrm{n} 20$, at 412

21 Prescott and Schofield, above n 14, at 76-77, argue that the first distinction to make is between islands and rocks. The next question is whether the rocks meet the criteria in art 121(3).

22 Symmons, above n 6, at 101. Van Dyke and Brooks suggest that the distinction may lie in whether the feature has "accompanying land": see above n 9, at 283.

23 Prescott and Schofield, above n 14, at 77.

24 Gjetnes describes a 1996 decision from the Supreme Court of Norway, in which the Court found that a feature of $13.2 \mathrm{~km}^{2}$ was too large to be a rock: see above n 13, at 193. See also Oude Elferink, above n 19, at 60 . 
was not the one taken by the Tribunal, possibly because all of the features in the Spratly Islands are comparatively small.

Prior to the South China Sea arbitration, the interpretation of art 121(3) had never been directly addressed by international courts or tribunals. In some cases, the issue had been raised by the parties to a maritime boundary dispute, for example arguing that an island should have lesser weight in the delimitation because it was a "rock" according to art 121(3). However, the courts considering these cases found it possible to reach a resolution of the matter without directly addressing the interpretation of the article. ${ }^{25}$

The matter arose in an unusual way in the International Tribunal for the Law of the Sea (ITLOS) on two occasions. In the Monte Confurco and Volga prompt release cases, Judge Vukas made statements to the effect that he did not believe that the claims of EEZs around the Kerguelan Islands (in the case of France) and the Heard and McDonald Islands (in the case of Australia) were valid under UNCLOS. ${ }^{26}$ In neither case had the parties to the dispute challenged the validity of the coastal state's maritime claim. The Judge's comments have been criticised by some commentators on the basis that the Kerguelan Islands are very substantial in size and their status had never before been called into question. ${ }^{27}$

\section{B The Tribunal's Conclusions on Article 121(3)}

The Arbitral Tribunal was asked by the Philippines to, among other matters, rule on whether any of the features in the Spratly Islands were capable of generating an EEZ or continental shelf. ${ }^{28}$ Therefore, once it found that it had jurisdiction, the Tribunal had to engage directly with the interpretation of art 121(3). ${ }^{29}$

The Tribunal discussed the meaning of art 121(3) in great detail and came to a number of significant conclusions. The Tribunal reached this interpretation by focusing on the text and context

25 Maritime Delimitation in the Black Sea (Romania v Ukraine) (Judgment) [2009] ICJ Rep 61 at 122 ; Territorial and Maritime Dispute (Nicaragua v Colombia) (Judgment) [2012] ICJ Rep 264 at 691-692. See Oude Elferink, above n 19 at 62; Symmons, above n 6, at 63; and Schofield, above n 14, at 333. But see Van Dyke, above n 7, at 449, who argued, in 1988, that the fact that tribunals and courts had refused to give full effect to uninhabited islands supports the proposition that uninhabited rocks and islets do not generate extended maritime jurisdiction.

26 Monte Confurco Case (Seychelles v France) (Judgment) (2000) 125 ILR 203; and Volga Case (Russian Federation v Australia) (Judgment), above n 12. Judge Vukas set out, in his separate declaration to the Volga case, his reasoning for reaching this conclusion, which was largely because the purpose for the creation of the EEZ was to provide access to fishing resources for local communities.

27 See Anderson, above n 14, at 311; Schofield, above n 17, at 30.

28 South China Sea Arbitration (Award), above n 1, at [112].

29 South China Sea Arbitration (Philippines v China) (Jurisdiction and Admissibility) (2016) 55 ILM 811 (PCA) [South China Sea Arbitration (Jurisdiction and Admissibility)]. 
of art 121(3) and referring to the travaux préparatoires of the provision. Article 121(3) also had to be seen in the context of other aspects of the Convention, including the reasons for creating EEZs. ${ }^{30}$ The Tribunal noted that during UNCLOS negotiations, there was significant disagreement about the formula to be applied in determining which features would receive EEZs and continental shelves, and that the final result was a compromise. ${ }^{31}$ Varying criteria such as size, proximity to other land, and the presence of fresh water were rejected during the negotiations. However, it found that art 121(3) was intended to disqualify high tide features from generating vast maritime zones that would encroach on the international seabed. ${ }^{32}$ The purpose of an EEZ was to support a coastal population, not to create a windfall for states that possessed remote features. ${ }^{33}$

The Tribunal's findings on the interpretation of art 121(3) are carefully considered and wideranging. The Tribunal adopted a strict position on the meaning of art 121(3), effectively setting a very high bar for small features to qualify for extended maritime zones.

First, the Tribunal found that a rock is any naturally formed area of land that is above high tide, irrespective of its composition. ${ }^{34}$ Therefore, sand banks that are above high tide could be a "rock". It concluded that the determination of whether a feature is a rock capable of human habitation or an economic life of its own relies on the natural state of the rock and not on any human enhancements. ${ }^{35}$ China's enhancements to many of the features of the Spratly Islands would not change the classification of a feature under art 121.

Next, the Tribunal considered what it means for a rock to be "capable of human habitation". It found that human habitation requires more than the mere survival of small number of people on a feature for a short period. ${ }^{36}$ A community of people should be there by choice and, at a minimum, the feature should be able to provide food, drink and shelter to allow people to live there permanently or habitually over an extended period of time. ${ }^{37}$ The Tribunal believed that there needs to be a minimum proper standard of existence. ${ }^{38}$ The community does not need to be large, and periodic residence on

30 South China Sea Arbitration (Award), above n 1, at [536].

31 At [537]-[538].

32 At [535] and [537]. The Tribunal quoted a Danish representative as saying that the point of para 3 was to ensure that "tiny and barren islands, looked upon in the past as mere obstacles to navigation" from creating enormous maritime zones: at [533].

33 At [515]. See also Gjetnes, above n 13, at 194.

34 South China Sea Arbitration (Award), above n 1, at [481] and [540].

35 At [541].

36 At [489].

37 At [490].

38 At [487]. 
a feature by a nomadic people could be sufficient. ${ }^{39}$ The Tribunal noted the negotiators of UNCLOS were sensitive to the livelihoods of the populations of small island nations. ${ }^{40}$

The Tribunal found that a dependence on external supply would rule out a feature as sustaining human habitation or an economic life. However, this does not preclude islands that are part of a network supporting human habitation from meeting the criteria. ${ }^{41}$

Whether a feature is capable of sustaining human habitation is a matter that has to be addressed on a case by case basis. ${ }^{42}$ Evidence of physical conditions capable of ensuring survival is not sufficient. ${ }^{43}$ Instead, the Tribunal will consider the capacity to sustain settled habitation by a human community. ${ }^{44}$ This is best established by an examination of the historical use to which it has been put. If nothing resembling a stable community has resided there, it would be reasonable to conclude that the feature is not capable of sustaining human habitation. ${ }^{45}$ If the feature is inhabited but the habitation is only possible through outside support, it does not, in itself, sustain human habitation. ${ }^{46}$ If a population is installed on a feature solely to stake a claim to territory and maritime zones, this would be an attempt to defeat art 121(3) and should not be successful. ${ }^{47}$

The Tribunal considered that "a maritime feature will ordinarily only possess an economic life of its own if it is also inhabited by a stable human community". ${ }^{48}$ An exception might be where there is a network of related features, but the expectation is that they will be sustaining a population. Economic life must be oriented around the feature and not focused solely on the waters or seabed of the territorial sea. Extractive activities without the involvement of a local population would not meet this criterion. ${ }^{49}$

39 At [542].

40 At [542].

41 At [547].

42 At [546].

43 Conversely, if a feature lacks vegetation, drinking water or foodstuffs, then this indicates that it is incapable of sustaining human habitation: see at [548].

44 At [548].

45 At [549].

46 At [550].

47 At [550].

48 At [544]. This interpretation has been supported by some early writers on article 121(3): see Prescott and Schofield, above n 14, at 79. However, the authors note that other authors have been more open to other forms of economic life.

49 South China Sea Arbitration (Award), above n 1, at [543]. 
In applying these principles to the features in the Spratly Islands, the Tribunal found that all high tide elevations were rocks, incapable of sustaining human habitation or an economic life of their own. In particular, Itu Aba, the largest of the features, ${ }^{50}$ was a rock for the purposes of art 121(3) despite the presence of humans at various points in its history. The Tribunal found that fishermen who dwelt on the island for fairly lengthy periods of time did not consider themselves inhabitants of the island. ${ }^{51}$ Several mining operations, which saw between 200 and 600 people living on Itu Aba in the 1920 s, ${ }^{52}$ amounted to temporary occupation solely for extractive purposes. ${ }^{53}$ The government and military personnel living on Itu Aba were not there by choice, but to advance the claim to sovereignty. ${ }^{54}$

The Tribunal's application of these principles to Itu Aba has naturally raised questions about whether claims from other features around the world are valid.

\section{NEW ZEALAND'S OFFSHORE ISLANDS}

This section considers the Tribunal's analysis of art 121(3) and asks whether New Zealand's offshore islands would be eligible for EEZ and continental shelf under that approach.

\section{A New Zealand's Islands}

New Zealand's EEZ and continental shelf are based to a significant extent on the existence of offshore islands. There are seven significant features that form the basis of the EEZ. New Zealand deposited the baselines from which it measures the EEZ and continental shelf with the United Nations in March 2006. ${ }^{55}$

50 Itu Aba is approximately $1.4 \mathrm{~km}$ long, $400 \mathrm{~m}$ wide at its widest point and has a surface area of approximately $0.43 \mathrm{~km}^{2}$ : see at [401]. It has fresh water and fruit trees have grown on the feature.

51 At [618].

52 At [606].

53 At [619].

54 At [620].

55 Division for Ocean Affairs and the Law of the Sea Office of Legal Affairs "Maritime Zone Notification 56" (8 March 2006) <www.un.org >. 


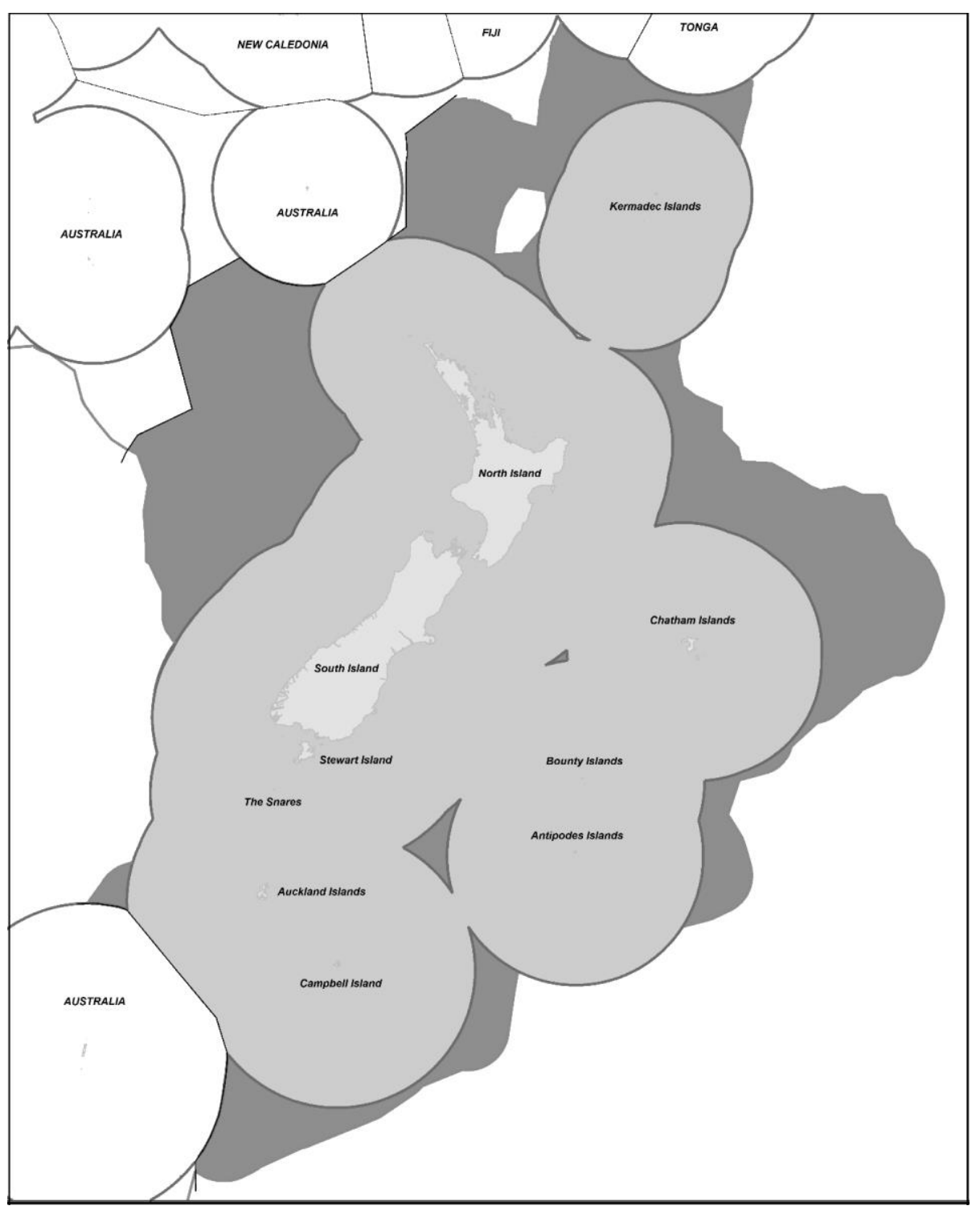

Figure 1: New Zealand's EEZ and continental shelf. Created by Stuart Kaye for the author. 


\section{The Chatham Islands}

The Chathams are the only example of current, permanent, habitation on New Zealand's offshore islands. The Chatham Islands are located $862 \mathrm{~km}$ east of Christchurch. The largest islands, Chatham and Pitt, have been inhabited since the 15th century. Currently, they sustain a population of around 600 people who are primarily involved in farming and fishing. There can be no doubt that the Chatham Islands are capable of generating extended maritime zones, and they will not be considered further.

\section{Kermadec Islands ${ }^{56}$}

The Kermadec Island chain is dispersed across a $200 \mathrm{~km}$ area to the north of the North Island. The main island, Raoul Island, has a land area of $29 \mathrm{~km}^{2}$, but the other islands total less than $4 \mathrm{~km}^{2}$. These islands were historically a stopover point for travellers between New Zealand and Polynesia. A few families settled on Raoul Island from the 1830s until a volcanic eruption in 1870. The Bell family lived there for 35 years from 1878. Their attempt to earn a living from the land was unsuccessful because of the lack of a safe landing place. During World War Two, coast-watchers were posted to Raoul Island to maintain a watch for enemy vessels. A meteorological station was created in 1939. The other islands in the Kermadecs largely lack good sources of fresh water, although they have extensive vegetation. The key exception is L'Esperance Rock in the Southern Kermadecs, which is $0.48 \mathrm{~km}^{2}$, rocky and barren.

\section{Auckland Islands ${ }^{57}$}

The Auckland Islands are $350 \mathrm{~km}$ south of Stewart Island. There is a history of short-lived settlements in this area. Between 1842 and 1856, a small number of Māori and Europeans attempted to create a settlement. However, this was abandoned due to the hostile weather conditions and a lack of whales. Other intermittent attempts were made to establish farming operations on the Auckland Islands. Coast-watchers were posted to these islands during World War II. The islands have been a nature reserve since 1934 .

\section{Campbell Island}

Campbell Island totals $113 \mathrm{~km}^{2}$ and is located $550 \mathrm{~km}$ south of Stewart Island. This was the location of more successful attempts to establish a farming settlement, which lasted from 1895 until 1931. However, the climate and lack of regular supply shipments meant that the efforts were ultimately unsuccessful. There was a coast-watcher programme on Campbell Island. A meteorological station was located there from 1945 until 1994. The island became a nature reserve in 1954.

56 Simon Nathan "Kermadec Islands" (12 September 2012) Te Ara - The Encyclopedia of New Zealand <www.TeAra.govt.nz>.

57 Jock Phillips "Subantarctic islands - Auckland and Campbell islands" (12 September 2012) Te Ara - the Encyclopedia of New Zealand, <www.TeAra.govt.nz>. 


\section{Antipodes Islands ${ }^{58}$}

The Antipodes Islands are $830 \mathrm{~km}$ south of Stewart Island. There are several islands, with a total area of $29 \mathrm{~km}^{2}$. The vegetation is primarily tussock and ferns. The islands were used as a base for sealers in the early 19 th century, when up to 80 sealers were located there for about two years, until the seal population became overharvested.

\section{Bounty Islands}

The Bounty Islands are 22 granite outcrops amounting to about 135 hectares. The features are largely barren, although they are home to a large seabird population.

\section{Snares Islands}

The Snares Islands, $100 \mathrm{~km}$ south of Stewart Island, are also granite in composition and, like the Bounty Islands, are home to many seabirds. The main island is $2.8 \mathrm{~km}^{2}$.

\section{B Applying the South China Sea Award Approach to New Zealand's Islands}

The first thing to note is that many of the features mentioned above are considerably larger than Itu Aba's $0.43 \mathrm{~km}^{2}$.

58 Jock Phillips "Subantarctic islands - Snares, Antipodes and Bounty islands" (12 September 2012) Te Ara the Encyclopedia of New Zealand, <www.TeAra.govt.nz>. 


\begin{tabular}{|l|l|l|l|l|l|l|l|}
\hline & $\begin{array}{c}\text { Itu } \\
\text { Aba }\end{array}$ & $\begin{array}{c}\text { Kermadec } \\
\text { Islands }\end{array}$ & $\begin{array}{c}\text { Auckland } \\
\text { Islands }\end{array}$ & $\begin{array}{c}\text { Campbell } \\
\text { Island }\end{array}$ & $\begin{array}{c}\text { Antipodes } \\
\text { Islands }\end{array}$ & $\begin{array}{c}\text { Bounty } \\
\text { Islands }\end{array}$ & $\begin{array}{c}\text { Snares } \\
\text { Islands }\end{array}$ \\
\hline Size $\left(\mathrm{km}^{2}\right)$ & 0.43 & $29.4^{59}$ & $461^{60}$ & $113^{61}$ & $20.9^{62}$ & $1.35^{63}$ & $2.8^{64}$ \\
\hline $\begin{array}{l}\text { Presence of } \\
\text { vegetation }\end{array}$ & Yes & Yes & Yes & Yes & Yes & No & Yes \\
\hline Fresh water & Yes & Yes & Yes & Yes & Yes & No & Yes \\
\hline $\begin{array}{l}\text { Extended } \\
\text { settlement }\end{array}$ & No & Some & Yes & Yes & No & No & No \\
\hline $\begin{array}{l}\text { Extractive } \\
\text { activity }\end{array}$ & Yes & Yes & Yes & Yes & Yes & No & No \\
\hline
\end{tabular}

\section{Auckland, Campbell and Kermadecs}

These three islands or island chains are large in comparison to Itu Aba. Of course, the Tribunal ruled out size as a dispositive factor. ${ }^{67}$ However, where a feature is $20 \mathrm{~km}^{2}$ (or more) in size, it does seem hard to regard it as a "rock". The Tribunal also considered the presence of fresh water and vegetation would not have an impact unless the case is borderline. ${ }^{68}$ In all cases, these islands have fresh water and vegetation.

The common feature of these islands, however, is that they have been inhabited by large or small communities at various times, but have not been inhabited in recent times apart from the presence of Department of Conservation staff at times. Previous settlements could be taken as evidence of the islands' capacity to sustain human habitation. The fact that the settlement on Raoul Island was for a

59 Raoul Island only: see Nathan, above n 56.

60 The nearby Adams Island (not included) is $102 \mathrm{~km}^{2}$ : email from Land Information New Zealand to the author.

61 Phillips, above n 57.

62 Phillips, above n 58.

63 Land area of all the islands. The largest island is $800 \mathrm{~m}$ long: see Phillips, above $\mathrm{n} 58$.

64 North East Island only: see Phillips, above n 58.

65 The water is of a poor quality: see Donald S Horning "The 1976-1977 Snares Islands Expedition" (18 April 1977) <docs.niwa.co.nz> at 10 .

66 There is no history of large-scale mineral extraction - resources extracted from New Zealand features were limited to seals or whales.

67 South China Sea Arbitration (Award), above n 1, at [538].

68 At [548]. 
time comprised of a single family is not necessarily an indication that it would fail to meet the Tribunal's criteria. The Tribunal stated that "a community need not necessarily be large, and in remote atolls a few individuals or family groups could well suffice". ${ }^{9}$ Of course, whilst the Tribunal was primarily considering small island nations in this paragraph, it could be argued to apply equally to Raoul Island. The question is whether the "intention of the population was truly to reside in and make their lives on the islands in question." 70 It seems fairly certain that all of the attempts to settle these islands were genuine efforts to create a home.

However, the Tribunal set a very high bar for recognising the capacity to sustain human habitation, especially in the case of features that are not currently inhabited: ${ }^{71}$

If the historical record of a feature indicates that nothing resembling a stable human community has ever developed there, the most reasonable conclusion would be that the natural conditions are simply too difficult for such a community to form and that the feature is not capable of sustaining such habitation. In such circumstances, the Tribunal should consider whether there is evidence that human habitation has been prevented or ended by forces that are separate from the intrinsic capacity of the feature. War, pollution, and environmental harm could all lead to the depopulation, for a prolonged period, of a feature that, in its natural state, was capable of human habitation. In the absence of such intervening forces, however, the Tribunal can reasonably conclude that a feature that has never historically sustained a human community lacks the capacity to sustain human habitation.

It seems difficult to argue that it was anything other than the intrinsic quality of the islands that ended some of the earliest attempts to settle these islands. The climate, isolation or sheer difficulty of eking out a living meant that settlements, even those that managed to survive for decades, did not continue over the long term.

However, the lack of more recent settlement may not be fatal to the claim to be an island. In particular, these features were designated as nature reserves well before the negotiation of UNCLOS. ${ }^{72}$ This designation would have prevented anyone so inclined from attempting to establish settlements more recently, when people may have been better equipped to create a sustainable life on those remote islands. This could arguably be the "force", separate from the intrinsic nature of the feature, that prevented habitation.

69 At [542].

70 At [542].

71 At [549].

72 Auckland Islands and Raoul Island in 1934 and Campbell Island in 1954. There are also marine reserves around the islands. For a discussion about whether marine reserves can meet the requirement for "an economic life of its own", see Jonathan L Hafetz "Fostering Protection of the Marine Environment and Economic Development: Article 121(3) of the Third Law of the Sea Convention" (2000) 15 Am U Int'l L Rev 583. 
The Tribunal was dismissive of situations where the settlement was highly dependent on outside support. "Where outside support is so significant that it constitutes a necessary condition for the inhabitation of a feature ... it is no longer the feature itself that sustains human habitation". ${ }^{73}$ There can be little doubt that the early colonies were highly dependent on supply from the outside for all but the very basics. This would undoubtedly be the case if a more modern settlement was created..$^{74}$ However, the distinction between supply as a "necessary condition" and supply as part of a trading relationship that makes life on a feature comfortable is very fine.

The size of the features and the fact that these islands have a history of human habitation indicate strongly that they are capable of sustaining human habitation. ${ }^{75}$ The absence of permanent communities from the 20th century onwards cannot be separated from the fact that settlement is currently forbidden by law. Although the Tribunal's comments, taken in isolation, could be the basis of a technical argument that these are "rocks", it seems unreasonable to conclude otherwise.

\section{Antipodes, Bounty and Snares}

It is likely that, if the Tribunal's logic is applied to these islands, that they could fall into the category of "rocks which cannot sustain human habitation or economic life of their own". None of them have a history of habitation.

The Bounty Islands in particular would struggle to meet the criteria established by the Tribunal. They are rocky outcrops, albeit reasonably large -22 features with a total land area of $1.35 \mathrm{~km}^{2}$. With no vegetation and no fresh water, they are the closest to a "rock". However, the Bounty Islands sit between the Antipodes Islands and the Chatham Islands, and generate a relatively small part of New Zealand's overall EEZ.

In contrast, the Antipodes Islands generate a large portion of the southeast part of the EEZ. Antipodes Island is large, with a land area of $20 \mathrm{~km}^{2}$. It has vegetation and fresh water. Nevertheless, the Tribunal did not accept that there is a maximum size at which a feature is no longer a rock. The presence of sealers on the Islands in the early 1800s would not have satisfied the Tribunal - it found that occupation of Itu Aba by fishermen for extended periods was not human habitation. Nor was the presence of large numbers of phosphate miners. If one applies the Tribunal's reasoning strictly, it would be difficult to argue that these islands are capable of sustaining human habitation or an economic life of their own.

Finally, the Snares Islands are smaller, with the largest island having a land area of $2.8 \mathrm{~km}^{2}$. This is still much larger than Itu Aba, but the conditions are arguably more hostile to human habitation. In

73 South China Sea Arbitration (Award), above n 1, at [550].

74 See below for a critique of this requirement.

75 It has been observed that islands are likely to become more capable of habitation or supporting an economic life as technology improves: see Prescott and Schofield, above n 14, at 78. 
reality, the Snares Islands have a minimal impact on New Zealand's EEZ. To the north, the EEZ is based around the South Island, and to the south are the Auckland Islands. The Snares Islands create a small "bump" in the EEZ in the Southwest corner.

Despite the relatively large size of these features compared to those of the Spratly Islands, if the criteria established by the Tribunal in the South China Sea arbitration were strictly applied, there is a risk that they would be found to be rocks which cannot sustain human habitation or an economic life of their own. However, this conclusion relies on a strict application of the Tribunal's reasoning to New Zealand's off-shore islands. The following sections explain why, if the matter came before an international court or tribunal, New Zealand's claims are likely to be upheld.

\section{A CRITIQUE OF THE SOUTH CHINA SEA ARBITRAL AWARD'S ANALYSIS OF ARTICLE 121(3)}

This section of the article explores critiques of the arbitral award in relation to the interpretation of art 121(3) and how it may not apply in future cases.

\section{A The South China Sea Arbitration is Binding Only on the Parties}

A coastal state whose claim is challenged would argue that the South China Sea case must be confined to its facts. Only the Philippines and China are bound by the arbitral decision. The ruling in that case is not determinative of other disputes and a future tribunal would not necessarily have to follow the interpretation set down by that decision. ${ }^{76}$ In some areas, including maritime delimitation, the jurisprudence of courts and tribunals has shifted over time, demonstrating that previous decisions are not determinative of future cases. ${ }^{77}$ Despite this shift, it is undeniable that courts and tribunals

76 Article 296(2) of UNCLOS provides that any decision by a court or tribunal with jurisdiction shall have no binding force except between the parties and in respect of that particular dispute. Compare the Statute of the International Court of Justice which holds that decisions of the Court have "no binding force except between the parties and in respect of that case" (art 59). See Continental Shelf (Libyan Arab Jamahiriya v Malta) (Application to Intervene, Judgment) [1984] ICJ Rep 3 at [42].

77 Alan Boyle "Further Development of the Law of the Sea Convention: Mechanisms for Change" (2005) 54 ICLQ 563 at 569 
take into account previous decisions, ${ }^{78}$ and a future court or tribunal hearing a dispute involving the interpretation of art 121(3) would carefully consider the outcome of the South China Sea arbitration. ${ }^{79}$

Nevertheless, two factors may give rise to caution for judges and arbitrators applying the reasoning of the South China Sea decision in future cases. The first is that China did not appear before the Tribunal. Although the Tribunal took into account detailed information made publicly available by China, it did not have the benefit of comprehensive arguments by counsel representing China. This does not undermine the binding nature of the decision between the parties, but raises the question as to whether the Tribunal may have come to a different interpretation if it had the benefit of full arguments.

A second factor is the political nature of the dispute before the Tribunal. The South China Sea is a highly contested area with numerous overlapping territorial and maritime claims. The Tribunal's decision makes it clear that it strongly condemned much of China's conduct. The conclusion that none of the relevant features were islands capable of generating exclusive economic zones arguably had several positive outcomes from a dispute resolution perspective. First, the system of compulsory dispute settlement established by UNCLOS contains a number of exclusions from jurisdiction. States can choose to exclude certain disputes, including maritime delimitation disputes. ${ }^{80}$ Because China has excluded maritime delimitation disputes from compulsory jurisdiction, had any of the features been capable of generating an EEZ, the Tribunal would not have had jurisdiction over the dispute. ${ }^{81}$ Secondly, the fact that none of the features are entitled to an EEZ greatly simplifies the potential legal issues in the South China Sea region, issues which are exacerbated by states claiming large maritime

78 For example, the ICJ refers to previous cases in its decision making and a series of cases establishing a principle of law will be highly persuasive. See Gilbert Guillaume "The Use of Precedent by International Judges and Arbitrators" (2011) 2 JIDS 5 at 9-10. This reflects a jurisdiction constante approach to the development of international law (at 10). Guillaume argues that precedent plays "a much lesser role" for arbitrators than judges (at 14), but acknowledges that, where arbitrators are members of international tribunals or academics in the area, they are often essentially faithful to the jurisprudence (at 15). See also Gabrielle Kaufmann-Kohler "Arbitral Precedent: Dream, Necessity or Excuse?" (2007) 23 Arbitration International 357.

79 A number of authors have noted the award has possible implications for other claims by coastal states: see for example Reed and Wong, above n 3, at 760; and Clive Schofield "A Landmark Decision in the South China Sea: The Scope and Implications of the Arbitral Tribunal's Award" (2016) Contemporary Southeast Asia: A Journal of International and Strategic Affairs 339 at 346.

80 UNCLOS, art 298(1).

81 South China Sea Arbitration (Jurisdiction and Admissibility), above n 29, at [394]; and South China Sea Arbitration (Award), above n 1, at [395] and [633]. If, for example, Itu Aba (controlled by Taiwan) generated an EEZ, this would overlap with that of the Philippines, which would have meant the dispute involved a maritime delimitation question and the Tribunal would not have had jurisdiction. 
zones from small features. ${ }^{82}$ Arguably, removing the entitlement to an EEZ and continental shelf makes the presence or absence of territorial sovereignty over the features less significant. These considerations may not be present in other situations, particularly in the case of New Zealand's maritime claims which have not been objected to by any state.

\section{$B$ The Case for a Different Interpretation or Application of Article 121(3)}

There are several grounds on which it could be argued in future proceedings that the Tribunal in the South China Sea arbitration was incorrect, either in its interpretation of art 121(3) of UNCLOS, or in its application of the Convention to the facts. While China's refusal to appear does not in itself undermine the legitimacy of the decision as between the parties, it may make it easier for a later tribunal to take a different approach to the interpretation of art 121(3) on the basis of arguments that were not presented to, or considered by, the South China Sea Tribunal.

\section{Absence of analysis of state practice}

The key basis for challenge is the Tribunal's interpretation of art 121(3). One obvious problem is that the decision failed to look at any examples of state practice in relation to art 121(3). The Tribunal briefly addressed whether state practice was relevant to the interpretation of UNCLOS. Article 31(3) of the Vienna Convention provides that "any subsequent practice in the application of the treaty which establishes the agreement of the parties regarding its interpretation" shall be taken into account in interpreting a treaty. ${ }^{83}$ The Tribunal correctly indicated that, in order for state practice to reach the standard of an agreement as to interpretation, it must be consistent and there is a high threshold to be met. ${ }^{84}$ It is true that there are many disputes about whether a particular feature is an art 121(3) rock or not. It has been a common feature of delimitation disputes that parties disagree about whether a feature can generate more than a territorial sea. ${ }^{85}$ However, it could be argued that a detailed examination of state practice would give a more nuanced indication as to how the international community has applied art 121(3). Of course, not all state practice will necessarily be useful. As Anderson has argued, "[a] state cannot change the interpretation of treaties and conventions by its own unilateral practice. One or two exaggerated interpretations do not change the true

82 This was acknowledged in argument by the Philippines. See Paul Gewirtz "Limits of Law in the South China Sea" (Brookings Center for East Asia Policy Studies, East Asia Policy Paper 8, May 2016) at 10; and McDorman, above n 13, at 303.

83 Vienna Convention of the Law of Treaties 1155 UNTS 18232 (concluded 23 May 1969).

84 South China Sea Arbitration (Award), above n 1, at [552].

85 See For example Maritime Delimitation in the Black Sea (Romania v Ukraine) (Judgment) [2009] ICJ Rep 61. 
interpretation." 86 However, where state practice has failed to produce protests by other states, this must be considered significant.

There are a number of features from which EEZs and continental shelves have been claimed that have not been protested that may, on the face of it, fail to meet the standard set by the Tribunal. Many of these features are small and lack water or vegetation. In some cases, these claims have stood for 40 years or more, during which time the coastal states have legislated and often enforced regulations in relation to the exploitation of the resources of the zones, without protest from other states. If the primary interest behind art 121(3) was focused on ensuring the maximisation of the commons areas (the high seas and the deep seabed) and limiting excessive claims, as proposed by the Tribunal, then one would have expected at least some protests by other states against these claims. ${ }^{87}$

The existence of these uncontested claims undermines the Tribunal's view that the travaux préparatoires revealed a consensus position on the interpretation of art 121(3). It has been suggested that it is impossible to determine from the travaux any particular agreement about how art 121(3) should be applied. ${ }^{88}$ Therefore, the practice of states following the conclusion of UNCLOS can be used to determine, if not what the proper interpretation is, then what it is not. And an examination of the uncontested claims indicates that only the very smallest and most isolated features would fall into art 121(3). ${ }^{89}$

It seems likely that any dispute over the classification of a feature has more to do with its location, rather than the characteristics of the rock itself. Where the feature has an impact on maritime boundary delimitation with other states, there is more likely to be a disagreement about whether it fits within art 121(3). ${ }^{90}$ Where the feature is remote, it is less likely to be challenged. ${ }^{91}$

In the face of such inconsistencies, how is the Tribunal to interpret art 121(3)? Rather than interpreting it in such a way as to risk invalidating 40 years of state practice, the Tribunal could have used this practice as evidence that the international community has interpreted art 121(3) relatively

86 David Anderson "Some Aspects of the Regime of Islands in the Law of the Sea" (2017) 32 International Journal of Marine and Coastal Law 316 at 319.

87 One exception is the protest by China against Japan's CLCS submission in respect of Okinotorishima, which pointed out the impact of the submission on the availability of seabed for the Area: see "Communication of the People's Republic of China to the Secretary-General of the United Nations" (6 February 2009).

88 Oude Elferink, above n 18, at 174.

89 At 174. Schofield has suggested that "States in possession of small islands have generally sought to maximize their maritime jurisdiction by advancing expansive maritime claims from such features": see above n 14, at 329. The main exception is Rockall, which the United Kingdom has agreed does not generate an exclusive economic zone or continental shelf.

90 Van Dyke, above n 7, at 464.

91 Symmons, above n 6, at 112. 
narrowly. Most disputes about the status of features are motivated primarily by a desire to maximise coastal state jurisdiction. In fact, one of the reasons that a court has never interpreted art 121(3) before this case is that the issue primarily arose in the context of delimitation disputes, where courts have been able to deal with the issues without addressing the article's correct interpretation. Where there is no delimitation or sovereignty dispute, states have apparently been tolerant of claims from smaller features.

\section{Logical inconsistencies}

Apart from the failure to consider state practice, some of the Tribunal's logic seems open to challenge. Nordquist and Phelan have suggested that errors were made by the Tribunal because it went well beyond the plain meaning of the words of art 121(3). ${ }^{92}$

One example is the Tribunal's suggestion that the capacity for human habitation depends on the ability of the island to support a human community without the external supply of provisions. Although the Tribunal acknowledged that small island states might be able to argue that a group of interconnected islands could support a community as a whole, it appeared to ignore the nature of human economic activity from the time that sea travel became regularised. It has not been uncommon across the centuries for small communities to form in a place where a resource or commodity found or grown locally can be traded to increase wealth. If trade routes are dependable, this allows human communities to be established in places that would not otherwise be sustainable. The reliance on external supply for some (or even most) items does not prevent that human community from identifying with that location and being successful. It is suggested that external supply should not disqualify a feature from being capable of human habitation. ${ }^{93}$

It is likely that the concern that the Tribunal was addressing was the idea that very tiny features could be completely provisioned from outside for the purposes of meeting the art 121(3) criteria. However, it was not necessary to rule out external supply for all features - rather the point was made that a community established for the purpose of meeting art 121(3) would not in itself meet the test, ${ }^{94}$ which is a far more reasonable approach. This conclusion would exclude the situations the Tribunal was really concerned with.

Conceptually, the requirement that a population associate with the feature rather than a distant place also ignores the idea that humans can make their life or livelihoods in a distant place but remain

92 Nordquist and Phelan, above n 13, at 31.

93 See for example Gjetnes, above n 13, at 198; Charney, above n 14, at 870; Kwiatkowska and Soons, above n 14, at 169; and Constantinos Yiallourides "Senkaku/Diaoyu: Are They Islands?" (2017) 50 The International Lawyer 347 at 356.

94 South China Sea Arbitration (Award), above n 1, at [550]. 
connected to a larger entity. ${ }^{95}$ Similarly, people can remain emotionally connected to a former home whilst living in another place. It is not clear why this should rule out the feature from being capable of human habitation. ${ }^{96}$

In a similar vein, the ruling out of the extraction of resources as being sufficient to establish the economic life of the feature is also extremely narrow and ignores the fact that human economic activity has traditionally been based on the exploitation of resources. Not all of these involve longexisting settlement. It seems rather surprising that extended periods of occupation of Itu Aba for the purposes of extracting resources could not create an economic life of its own. Certainly some states during the UNCLOS negotiations thought that the existence of natural resources would make them economically viable. ${ }^{97}$

Although the Tribunal was correct to find that parties to UNCLOS did not intend for small isolated features to generate EEZs, it went too far in its efforts to include Itu Aba in that category. The Tribunal referred to a comment by the Danish delegate that emphasised that art 121(3) was to prevent "tiny and barren islands, looked upon in the past as mere obstacles to navigation" from generating vast maritime zones. $^{98}$ It seems incongruous to characterise Itu Aba, with a length of $1.4 \mathrm{~km}$ and possessing a water supply and arable soil, as a "mere obstacle to navigation". 99

If the interpretation of article 121(3) comes before a court or tribunal in the future, it will have two options. First, the judges or arbitrators can follow the South China Sea Tribunal approach. It should be remembered that three of the arbitrators in that case are current or former members of the ITLOS. The others are highly respected law of the sea academics. This means that the decision will carry weight. However, a second option is that the later court or tribunal could confine the decision to the facts of that case, especially given the circumstances of the dispute. It is possible that, had China appeared in the proceedings to argue the case, some of the problems with the reasoning of the Tribunal could have been avoided. This is a reason for treating the Tribunal's conclusions with considerable caution.

95 The Tribunal found that fishermen who resided on Itu Aba for extended periods of time did not intend to settle on the island and associated with Hainan and other places rather than Itu Aba.

96 Jiangyu Wang "Legitimacy, Jurisdiction and Merits in the South China Sea Arbitration: Chinese Perspectives and International Law" (2017) 22 Journal of Chinese Political Science 185 at 206.

97 Charney, above n 14, at 867.

98 South China Sea Arbitration (Award), above n 1, at [533].

99 Paul Gewirtz (writing before the decision was released) suggested that, to find that Itu Aba was a rock, would defy "what ordinary human beings would conclude and common sense would suggest." See Gewirtz, above n 82 , at 9 . 


\section{ARGUMENTS BASED ON ACQUIESCENCE OR ESTOPPEL}

If a later court does adopt the interpretation taken in the South China Sea arbitration, it is not necessarily true that a maritime claim based on a small feature that has never been challenged by other states will fail. A second argument may be that the maritime zone has been confirmed due to the uncontested exercise of rights. Where a state has claimed an EEZ and continental shelf from a small off-shore feature for a long period of time and it has consistently exercised its rights accordingly without any objection from other states, it can be argued that the international community has acquiesced in the coastal state's interpretation of art 121 to the effect that the feature can generate an EEZ and continental shelf.

\section{A Acquiescence and Estoppel in International Law}

Acquiescence has been described as the inaction of a state which is faced with a situation constituting a threat to or infringement of its rights. ${ }^{100}$ It essentially involves consent to a state of affairs through silence. Acquiescence has been used to confirm a state's rights in several circumstances. In the Temple of Prear Vihear case, the ICJ decided that Thailand's silence in the face of a map showing a boundary indicated assent to the boundary. ${ }^{101}$ The ICJ decided that: ${ }^{102}$

... the circumstances were such as called for some reaction, within a reasonable period, on the part of the Siamese authorities, if they wished to disagree with the map or had any serious question to raise in regard

to it. They did not do so, either then or for many years, and thereby must be held to have acquiesced.

In the Gulf of Maine case, a Chamber of the ICJ found that acquiescence and estoppel are different aspects of "the same institution" which follow from the principles of good faith and equity. ${ }^{103}$ Acquiescence, according to the Court, "is equivalent to tacit recognition manifested by unilateral conduct which the other party may interpret as consent". ${ }^{104}$ In that case, the issue involved the delimitation between two countries, who were directly concerned with the outcome, and the Court found that key members of the government knew about the map. There is a question whether acquiescence can be based on silence in the face of a map produced in respect of a far-distant state.

Some might suggest that it is inappropriate to use acquiescence to obtain an outcome that is inconsistent with the "proper" interpretation of UNCLOS. One interpretation of acquiescence is that a state gains rights it would not otherwise have but for the acquiescence, similar to historic rights. Another view is that silence in response to a state's unilateral assertion of its right is seen as agreement

100 IC MacGibbon "The Scope of Acquiescence in International Law" (1954) 31 BYIL 143.

101 Temple of Preah Vihear (Cambodia v Thailand) (Merits) [1962] ICJ Rep 6.

102 At 23 .

103 Gulf of Maine (Canada v Unites States of America) (Judgment) [1984] ICJ Rep 246 at 305.

104 At 305 . 
with the actions and claims and their legal implications. ${ }^{105}$ In the South China Sea arbitration, the Tribunal found that the EEZ regime conferred exclusive sovereign rights to the resources of the zone on the coastal state, which superseded any historic rights that a state may have had in the area. ${ }^{106}$ Historic rights are rights that a state would not otherwise hold, were it not for the operation of the historical process giving rise to the right and the acquiescence of other states in the process. ${ }^{107}$ In an interesting paragraph, the Tribunal noted that it was not considering the extent to which the Convention can be modified by state practice. The Award went on to outline what might be needed for state practice to modify the operation of the Convention: ${ }^{108}$

It is sufficient to say that a unilateral act alone is not sufficient. Such a claim would require the same elements discussed above with respect to historic rights: the assertion by a State of a right at variance with the Convention, acquiescence therein by the other States Parties, and the passage of sufficient time to establish beyond doubt the existence of both the right and a general acquiescence.

However, reliance on acquiescence on the part of a coastal state with an unchallenged claim to an EEZ would not amount to claim to historic rights in the sense that the Tribunal discussed them. Rather, it is an acceptance of the coastal state's interpretation of the Convention in relation to particular features from which it claims extended maritime zones. Evidence of the inaction of a party may be of value in interpreting a treaty. As MacGibbon stated in his seminal article:109

The failure of one party to a treaty to protest against acts of the other party in which a particular interpretation of the terms of the treaty is clearly asserted affords cogent evidence of the understanding of the parties of their respective rights and obligations under the treaty.

One possible objection to an argument based on acquiescence is that a state has no reason to object to a far-distant coastal state's EEZ claim until its own rights have been infringed. For example, if a coastal state were to arrest a foreign fishing vessel in an EEZ off a small feature, the flag state might suggest that this is the first opportunity it has had to object to the claim, and it would be unreasonable to expect it to object earlier. ${ }^{110}$

105 Georg M Berrisch "The Establishment of New Law Through Subsequent Practice in GATT"(1991) 16 NC J Int'l L \& Com Reg 497 at 504.

106 South China Sea Arbitration (Award), above n 1, at [245]-[247] and [261]-[262].

107 At [268].

108 At [275].

109 See generally MacGibbon, above n 100.

110 MacGibbon notes that it would not be appropriate to imply consent from silence in circumstances where a state does not have actual or constructive knowledge of the acts to which the alleged acquiescence relates: at 172 . 
In the context of the validity of claims to maritime zones, this argument is weak. First, the final form of article 121 was hotly contested during the negotiations for UNCLOS. States that were concerned about the way in which other states interpreted this article were effectively put on notice at that stage. States did raise objections when other states claimed EEZs or continental shelves from small features, although these were usually in relation to features that impacted on maritime delimitation issues. Second, coastal states are obligated to give publicity to the outer limits of their EEZs and continental shelves, meaning that there is no lack of clarity as to the maritime zones claimed by a state. ${ }^{111}$ Many states have communicated their disagreement with other states' EEZ or continental shelf claims. ${ }^{112}$ Third, the nature of the claim to maritime zones is different to other types of exercise of state jurisdiction in that it is an ongoing claim to the existence of sovereign rights as opposed to a one-off exercise of jurisdiction.

Provided a claim to acquiescence meets certain criteria, it can arguably be used to confirm a coastal state's maritime zones from small features. First, the coastal state's claim must be clear and communicated in a way that would draw protest or comment. Second, the acquiescence should be universal. Third, sufficient time must have passed to allow all states to be aware of the coastal state's position and have an opportunity to protest. ${ }^{113}$ The following section uses the example of New Zealand's off-shore islands to demonstrate how these criteria could be met.

\section{B The Facts Demonstrating Acquiescence in Relation to New Zealand's Maritime Claims}

There are a number of ways that states can make their claim to an EEZ and continental shelf from a feature sufficiently clear so that other states are aware of the claim. In New Zealand's case, there are four distinct ways in which it has made its claims known. In each instance, there were opportunities for objections from other members of the international community. First, the coastal state will publish the outer limits of their EEZ on charts that are given publicity. One requirement is that these charts are deposited with the Secretary-General of the United Nations pursuant to art 75(2) of UNCLOS. New Zealand deposited charts to this effect in 2006, which are available on the United Nations website. ${ }^{114}$ No objections have been received by the Secretary-General to those charts. ${ }^{115}$ However,

111 UNCLOS, arts 75 and 84.

112 See generally Division for Ocean Affairs and the Law of the Sea "Deposit of Charts" (5 September 2017) <www.un.org>; and Division for Ocean Affairs and the Law of the Sea "Submissions, through the SecretaryGeneral of the United Nations, to the Commission on the Limits of the Continental Shelf, pursuant to article 76, paragraph 8, of the United Nations Convention on the Law of the Sea of 10 December 1982" <www.un.org>.

113 MacGibbon, above n 100, at 143 .

114 See "New Zealand" (23 September 2016) Division for Ocean Affairs and the Law of the Sea <www.un.org>.

115 Contrast this with the communication regarding Clipperton Island lodged by Mexico in relation to France's deposit of maritime boundaries: see "France" (22 November 2016) Division for Ocean Affairs and the Law 
New Zealand has exercised sovereign rights over its EEZ since 1977 when it was first established in legislation. ${ }^{116}$ The outer limits of the EEZ has appeared on maritime charts since that time. At all times the EEZ has included areas generated from the off-shore islands discussed above.

Second, the coastal state may have made submissions to the Commission on the Limits of the Continental Shelf (CLCS) in relation to the outer limits of its continental shelf beyond 200 nautical miles. New Zealand deposited its submission to the CLCS on 19 April 2006. ${ }^{117}$ Five states made comments on the submissions: three in respect of possible overlapping boundaries with the extended continental shelf; and two in respect of New Zealand's decision not to submit coordinates for the Antarctic continental shelf. The latter comments repeated the position that the states involved did not accept any claims to sovereignty in Antarctica. However, no state made any objection to New Zealand's claim to a continental shelf generated from any of New Zealand's offshore islands.

The latter point is particularly pertinent. According to art 76(8), limits of the continental shelf established on the basis of recommendations of the CLCS "shall be final and binding". There is some debate about whether this means simply that the coastal state cannot change the boundaries or whether it is final and binding against other states. ${ }^{118}$ However, in the Bay of Bengal case, the ITLOS found that the outer limits were opposable to other states once the process in art 76(8) was complete. ${ }^{119}$ The CLCS has indicated that it is not willing to consider claims to outer limits in cases where there is a land or maritime delimitation dispute. Therefore, the Commission has not yet considered Japan's submissions in respect of Okinotorishima on the basis that both the People's Republic of China and the Republic of Korea have challenged the legal basis of the claim according to art 121(3). ${ }^{120}$ This

of the Sea <www.un.org>. Other objections to the deposit of EEZ coordinates have been received, usually related to disputed sovereignty over territory or how the coastal state has calculated the baselines that generate the EEZ.

116 Territorial Sea and Exclusive Economic Zone Act 1977.

117 "Submission by New Zealand" (20 August 2009) Division for Ocean Affairs and the Law of the Sea <www.un.org>.

118 For the first view, see Ted L McDorman "The Role of the Commission on the Limits of the Continental Shelf: A Technical Body in a Political World" (2002) 10 International Journal of Marine and Coastal Law 301 at 315. For the second view, see ILA Committee on the Legal Issues of the Outer Continental Shelf "Toronto Conference (2006): Legal Issues of the Outer Continental Shelf (Second Report)" (2006) International Law Association <www.ila-hq.org> at 16.

119 Delimitation of the Maritime Boundary between Bangladesh and Myanmar in the Bay of Bengal (Bangladesh v Myanmar) (Judgment) (2012) 51 ILM 844 at [407].

120 See Communications from China (6 February 2009) and the Republic of Korea (27 February 2009) regarding "Outer limits of the continental shelf beyond 200 nautical miles from the baselines: Submissions to the Commission: Submission by Japan" Division for Ocean Affairs and the Law of the Sea <www.un.org>. Japan disagrees with the conclusion that the CLCS cannot look at the submissions, arguing there is no dispute about maritime delimitation. See Japanese Communications (25 March 2009, 9 August 2011, 15 August 2011 and 9 April 2012). 
process means that the international community has a clear method of expressing an objection to a claim to a continental shelf generated from a small feature. In light of this, it is arguable that a court or tribunal would not be able to revisit a state's "final and binding" outer limits where no objection was raised before the CLCS. ${ }^{121}$

Third, the coastal state will generally exercise control over the EEZ and continental shelf through regulating fishing and hydrocarbon activities in the area. No foreign state has objected to New Zealand's exercise of jurisdiction in its EEZ.

Fourth, the coastal state may have entered into treaties regarding the delimitation of the extended maritime zone with other states, or in relation to fishing in its EEZ. New Zealand did this at the time of the negotiations for UNCLOS. New Zealand declared its EEZ in 1977, well before the conclusion of the negotiations, but at a time that the EEZ concept was widely accepted as reflecting international practice. ${ }^{122}$ In order to ensure that relevant states did not object, New Zealand entered into treaties with countries whose nationals traditionally fished in the high seas around New Zealand, which were subsequently absorbed into the EEZ. These were the USSR, ${ }^{123}$ the Republic of Korea, ${ }^{124}$ and Japan. ${ }^{125}$ In these treaties, the states accepted the jurisdiction of New Zealand over its EEZ and its sovereign rights to manage the fisheries in return for access to those fisheries. Those countries expressly accepted that New Zealand's maritime claims were appropriate and estoppel would prevent them challenging that position.

In summary, New Zealand has given due publicity to its EEZ and continental shelf through legislation, the exercise of sovereign rights and filling its obligations to deposit coordinates with the United Nations and make submissions to the CLCS. The fact that New Zealand has used off-shore islands to generate extended maritime zones is abundantly clear to any state. There have been opportunities to offer objections to New Zealand's claim, both bilaterally and through the United Nations system. However, no objections have ever been received. Finally, the passage of time has allowed for states to become aware of New Zealand's claims. The EEZ was established in 1977, 40 years ago. In these circumstances it would be contrary to principles of equity and stability to overturn decades of practice on the basis of an interpretation of article 121(3) which is highly controversial.

121 The author is indebted to Professor Natalie Klein for drawing her attention to this argument.

122 Territorial Sea, Contiguous Zone, and Exclusive Economic Zone Act 1977.

123 See Agreement on Fisheries between the Government of New Zealand and the Government of the Union of Soviet Socialist Republics 1151 UNTS 273 (signed 4 April 1978).

124 See Agreement on Fisheries between the Government of Korea and the Government of New Zealand 1167 UNTS 415 (signed 16 March 1978).

125 See Agreement on Fisheries between the Government of New Zealand and the Government of Japan, Memorandum of Understanding and Exchange of Letters (1 September 1978) 1167 UNTS 441. 


\section{CONCLUSION}

It may be hard to imagine that states with a history of active acceptance of New Zealand's maritime claims would have an incentive to challenge them now. However, it is not inconceivable that the uncertainty generated by the Tribunal's award could create some difficulties in practice. The Volga and Monte Confurco cases provide a hint as to how the issue could arise. In a situation where New Zealand arrests a foreign fishing vessel operating in a part of the EEZ generated from an offshore island, it is possible that the flag state could attempt to challenge the legitimacy of the EEZ based on art 121(3). Where the flag state is a flag of convenience and the legal strategy is driven by lawyers hired by the fishing company, this possibility is increased. This article has set out the reasons why this challenge is unlikely to be successful.

However, the very existence of the possibility may act as a damper on some coastal states' enthusiasm to enforce fishing regulations against foreign fishing vessels in EEZs around features whose status is ambiguous. If this does occur, it would be unfortunate for the governance of fisheries resources.

Another approach is that a coastal state, wishing to clarify the issues discussed above, could take a more assertive approach to inspecting foreign fishing vessels in its EEZ. One outcome could be the generation of a case along the lines mentioned above, in which case the coastal state has an opportunity to argue for a different interpretation of art 121(3). This may be unattractive for states as there is the risk that the result could be unfavourable. A more positive outcome from an active enforcement policy is that having a number of states accept the enforcement action adds weight to the argument that the international community has acquiesced to the coastal state's claim.

One of the goals of UNCLOS was to establish a law-based order, in part relying on certainty surrounding maritime zones and jurisdiction. It represented significant progress in comparison to the previous decades of instability arising from competing claims to a variety of maritime zones and coastal state jurisdiction. Although it is inevitable that states will disagree about particular aspects of interpretation of the treaty, the up-ending of maritime zones that have stood unchallenged for 40 years or more as the result of one tribunal decision would not be a positive contribution to the order of the seas. 
